\title{
THORACOLUMBAR EPIDURAL ARACHNOID CYST OF DIFFICULT CLINICAL MANAGEMENT: CASE REPORT
}

\author{
CISTO EPIDURAL ARACNOÍDEO TÓRACO-LOMBAR DE DIFÍCIL TRATAMENTO CLÍNICO: \\ RELATO DE CASO
}

\section{QUISTE ARACNOIDEO EPIDURAL TORACOLUMBAR DE DIFICIL TRATAMIENTO CLÍNICO: REPORTE DE CASO}

\author{
Francisco Alves de Araújo Júnior ${ }^{1,2}$, Dafne luana Bayer ${ }^{2}$, Hugo Akio Hasegawa ${ }^{2}$, Talita Ribeiro da Silva ${ }^{2}$, Johnni Zamponi Jr. ${ }^{1}$, Patricia Yokoo \\ 1. Hospital Universitário Evangélico de Curitiba (HUEC), Curitiba, PR, Brazil. \\ 2. Faculdade Evangélica do Paraná (FEPAR), Curitiba, PR, Brazil.
}

\begin{abstract}
Introduction: Among the primary lesions occupying the spinal space, only $1 \%$ corresponds to the epidural arachnoid cyst (EAC). This condition is usually asymptomatic, and identified accidentally in imaging tests. In symptomatic cases, total surgical resection is recommended. Objective: To describe a case of EAC refractory to clinical treatment. Methods: A 45-year-old woman had lumbar pain for six years and increased pain in the last months, with irradiation to the left lower limb (corresponding to L1). No other alterations found in the physical examination. Magnetic resonance imaging (MRI) of the spine revealed an intravertebral cystic lesion at T12-L1 level, in the left posterolateral position, causing enlargement of the foramen, and suggesting an epidural arachnoid cyst. Results: Due to failure of the initial clinical treatment, the patient underwent left T12-L1 hemilaminectomy, resection of the cyst and correction of dural failure. The patient progressed with effective pain control and MRI confirmed absence of residual lesion. Conclusion: EAC is more common in men (4:1) and may be congenital or acquired. The most common topography is thoracic (65\%). Its clinical presentation is low back pain, lower limb pain and paresthesia. MRI is the method of choice for diagnosis and surgical intervention is restricted to cases that are symptomatic or refractory to clinical treatment, and the prognosis tends to be excellent. We conclude that, in addition to being a rare and commonly asymptomatic condition, an adequate therapeutic approach is essential for complete cure, avoiding intense pain and manifestations that bring about a drastic reduction of functional capacity. Level of evidence: IV. Type of study: Case series.
\end{abstract}

Keywords: Cysts; Arachnoid cysts; Low back pain; Central nervous system cysts; Spinal cord.

\section{RESUMO}

Introdução: dentre as lesões primárias que ocupam o espaço espinhal, apenas 1\% corresponde ao cisto epidural aracnoideo (CEA). Esta patologia costuma ser assintomática, identificada acidentalmente em exames de imagem. Já em casos sintomáticos, a ressecção cirúrgica total é recomendada. Objetivos: descrever um caso de CEA refratário a tratamento clínico. Metódos: mulher, 45 anos, lombalgia há seis anos, com piora nos últimos meses e irradiação para membro inferior esquerdo (correspondente a L1). Sem demais alterações ao exame físico. A Ressonância magnética (RM) de coluna vertebral evidenciou lesão cística intravertebral a nível de T12 - L1, em situação póstero-lateral esquerda, provocando alargamento do forame, sugestivo de cisto epiduralaracnóideo. Resultados: Devido a falha do tratamento clínico inicial, a paciente foi submetida a hemilaminectomia de T12 - L1 à esquerda, ressecção do cisto e correção da falha dural. Evoluiu com controle álgico efetivo e RM de controle confirmou ausência de lesão residual. Conclusão: O CEA é mais comum em homens (4:1) e pode ser congênito ou adquirido. A topografia mais comum é a nível torácico (65\%). Apresenta-se clinicamente com lombalgia, dor em membros inferiores e parestesias. A RM é o método diagnóstico de escolha e a intervenção cirúrgica é restrita aos casos sintomáticos ou refratários ao tratamento clínico e o prognóstico tende a ser excelente. Concluímos que, além de ser uma patologia rara e comumente assintomática, é essencial a adequada abordagem terapêutica para que ocorra cura completa, evitando quadros álgicos intensos e manifestações que cursem com drástica redução da capacidade funcional. Nível de evidência: IV. Tipo de Estudo: Série de casos.

Descritores: Cistos; Cistos aracnóideos; Dor Lombar; Cistos do Sistema Nervoso Central; Medula espinhal.

\section{RESUMEN}

Introducción: Entre las lesiones primarias que ocupan el espacio espinal, solo el 1\% corresponde al quiste aracnoideo epidural (QAE). Esta patología generalmente es asintomática e identificada accidentalmente en pruebas de imagen. En casos sintomáticos, se recomienda la resección quirúrgica total. Objetivo: Describir un caso de QAE refractario al tratamiento clínico. Métodos: Mujer de 45 años tuvo dolor lumbar durante seis años y un aumento del dolor en los últimos meses, con irradiación a la extremidad inferior izquierda (que corresponde a $L 1$ ). No se encontraron otras alteraciones en el examen físico. La resonancia magnética (RM) de la columna vertebral reveló una lesión quística intravertebral en el nivel T12-L1, en la posición posterolateral izquierda, causando agrandamiento del foramen y sugiriendo un quiste aracnoideo epidural. Resultados: Debido a la falla del tratamiento clínico inicial, la paciente fue sometida a hemilaminectomía T12-L1 izquierda, resección del quiste y corrección de la falla dural. Ella progresó con un control eficaz del dolor y la RM confirmó la ausencia de lesión residual. Conclusión: EL QAE es más común en hombres (4:1) y puede ser congénito o adquirido. La topografía más común es torácica (65\%). Su presentación clínica es lumbalgia, dolor en las extremidades inferiores y parestesia. La RM es el método de elección para el diagnóstico y la intervención quirúrgica se limita a los casos que son sintomáticos o refractarios al tratamiento clínico, y el pronóstico tiende a ser excelente. Concluimos que, además de ser una condición rara y comúnmente asintomática, un abordaje terapéutico adecuado es esencial para una curación completa, evitando el dolor intenso y las manifestaciones que provocan una reducción drástica de la capacidad funcional. Nivel de evidencia: IV. Serie de casos.

Descriptores: Quistes; Quistes aracnoideos; Dolor de la región lumbar; Quistes del sistema nervioso central; Médula espinal. 


\section{INTRODUCTION}

Among all the primary lesions that occupy the spinal space, only $1 \%$ corresponds to the epidural arachnoid cyst (EAC). ${ }^{1-2}$

These cysts are more common in men, with peak incidence in the second decade of life, and are generally located posterior to the spinal cord. ${ }^{3}$

The etiology and pathogenesis of the epidural arachnoid cysts remain vague and uncertain. ${ }^{4}$

Such pathology is usually asymptomatic and often is an incidental finding in imaging tests. As regards treatment, symptomatic patients are candidates for surgical cystic resection and dural repair. ${ }^{5}$

The objective of this study was to describe a young female patient with symptomatic idiopathic EAC, in addition to the approach chosen by the team, her prognosis, and postoperative follow-up.

\section{METHODS}

The case data presented were collected from an analysis of the electronic medical records of the Hospital Universitário Evangélico de Curitiba.

Because this is a case history, there was no need for approval of this article by the institutional review board. The patient signed the informed consent form (ICF), confirming her knowledge of the use of her data for the publication of this article.

\section{CASE REPORT / RESULTS}

\section{Clinical findings}

The patient was a 45-year-old female, suffering with back pain since 2011 and worsening over the last year (2015), when it began to radiate bilaterally into the thoracic cage, being more intense on the left, in addition to pain radiating to the left lower limb in the topography of an L1 dermatome and causing claudication. The patient was being followed-up by the rheumatology team in the outpatient service of the Hospital Universitário Evangélico de Curitiba (HUEC) and managed clinically with analgesics, neuropathic pain modulators, in addition to non-steroidal anti-inflammatory drugs. However, the pain was no longer being controlled and she was referred to the neurosurgery outpatient clinic at the end of 2014

No neurological changes were observed in the physical examination.

\section{Complementary examinations}

Magnetic resonance imaging (MRI) of the thoracic spine (Figures 1 and 2) revealed an intervertebral cystic lesion at level T12-L1, hyperintense in the T2-weighted sequence and hypointense in T1, suggesting a diagnosis of an epidural arachnoid cyst.

\section{Surgical treatment}

A decision to perform surgical intervention was made because the patient did not respond to the clinical treatment. The patient underwent a left side hemilaminectomy of T12 and L1 on 06/29/2015. During the operation, an epidural cystic lesion with a good cleavage plane with the dural sac for almost its entire extension was observed, but it was joined to the root of T12 where communication with the subarachnoid space was observed.
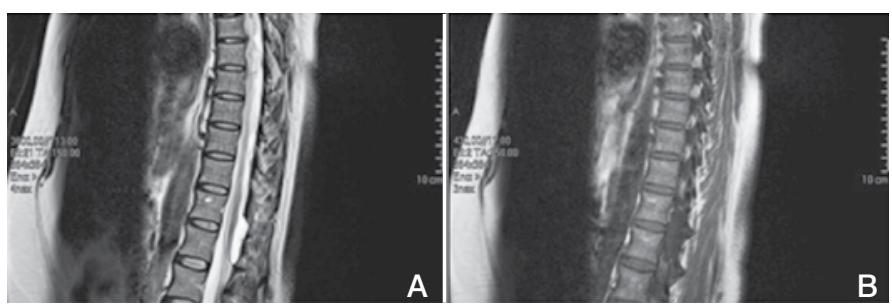

Figure 1. Parasagittal MRI slice - the thoracolumbar spine showing expansive epidural lesion at level T12-L1, hyperintense in the T2 weighted sequence (A) and hypointense in $\mathrm{T} 1 \mathrm{~B})$.

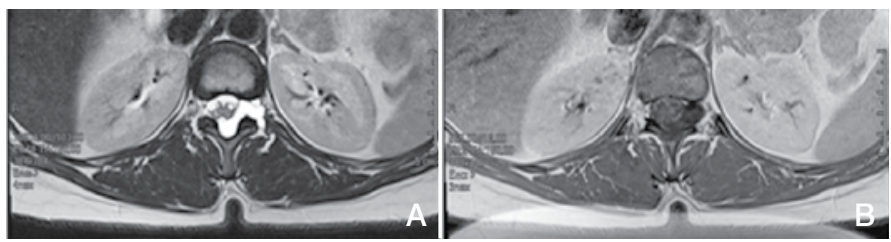

Figure 2. Axial MRI slice showing expansive epidural lesion at the vertebral foramen of the posterior root of $L 1$ on the left, T2 weighted image (A) and T1 post contrast (B)

The cyst was totally resected and the dural failure found was corrected with fibrin glue. The surgical specimen was referred for anatomopathological study.

\section{Anatomo-pathology}

The surgical specimen was prepared in hematoxylin and eosin stain and the microscope revealed fibrous tissue, dense with thick parallel layers; however, it could not be confirmed whether it was arachnoid or dura mater. No neoplastic signs were identified.

\section{Postoperative}

In the postoperative period, there was no onset of neurological deficit. On the second postoperative day (POD), the patient evolved with improved symptoms, complaining only of pain in the surgical wound. On POD 3, an MRI of the spine revealed "postoperative status" and total resection of the lesion.

The patient was discharged on POD 4 and remained stable during her outpatient follow-up with effective pain control. Currently, the patient is in outpatient follow-up and is asymptomatic.

\section{DISCUSSION}

The epidural arachnoid cyst was first described by Spiller in 1903 and is a rare etiology responsible for spinal cord compression, usually occurring in the lower thoracic spine, although there have been cases reported in the lumbar (65\%), lumbosacral (13\%), thoracolumbar $(12 \%)$ - as in the case presented - and sacral $(6 \%)$ regions. ${ }^{6}$

These cysts come from a hernial protrusion of the arachnoid membrane through minimal defects present in the constitution of the dura mater and can cause variable compressive symptomology depending on their size and location. ${ }^{7}$ However, the formation mechanism itself is not completely clear and various theories have been proposed, among them those that are congenital or secondary to other etiologies, such as arachnoid adhesions (from viral or bacterial infections), post subarachnoid hemorrhage arachnoiditis, spinal anesthetics, meningitis, and even traumatic causes. ${ }^{8}$

The presence of EAC in siblings, reported in isolated cases, indicates a probable genetic and congenital influence on the etiology of this disease. This theory is reinforced when we observe articles relating it to diseases with neural tube defects, such as spina bifida and diastematomyelia. ${ }^{9}$ In this pathology, the arachnoid may be enlarged due to the mechanism of nerve root movement or a change in the spinal pressure associated with pulsation, respiration, and coughing. ${ }^{10}$

Anatomically, the wall of the EAC consists of fibrous connective tissue with a fine epithelial arachnoid layer, which may be absent in the histopathological analysis. ${ }^{11}$

Nabors et al. standardized the classification of spinal meningeal cysts into three categories: epidural cysts without spinal nerve fibers (type I), epidural cysts with spinal nerve roots (type II), and intradural cysts (type III). Type I can be subdivided into IA -meningeal epidural cyst or epidural arachnoid cyst, which are more common - and IB referring to sacral meningoceles or occult sacral meningoceles. ${ }^{12}$ The patient in this case report corresponds to type II.

Because it is commonly asymptomatic, with the advent of the MRI, cases of incidental EAC are more frequently observed in imaging exams. ${ }^{13}$

In symptomatic patients, we can observe pain, paresthesia, intermittent neurogenic claudication, intestinal/genito-urinary dysfunction, and varying degrees of paresis. ${ }^{2}$ 
The clinical profile is generally a result of spinal cord or nerve root compression and in most cases the symptoms are asymmetrical and fluctuating, with remissions and exacerbations (30\% of cases). ${ }^{1-2}$ This pattern is mainly explained by the valved opening in the communication between the cyst and subarachnoid space (either by Valsalva maneuvers or gravitational force), leading to its progressive growth. The entrance of water promotes volume growth of the cyst. The secretory role of the cyst walls has not been proven. ${ }^{14}$

The literature also reports the occurrence of kyphosis in a third of the cases as a result of segmental paralysis of the muscles responsible for spinal erection or by bone destruction caused by the presence of the cyst. ${ }^{13}$ Horner's syndrome is a common presentation in patients whose cysts occur in the low cervical spine. ${ }^{15}$ Additionally, herniation of the spinal cord due to a defect in the dura mater in asymptomatic EAC can be a rare cause of acute paraplegia or Brown-Séquard syndrome. ${ }^{16}$

$\mathrm{MRI}$ is the procedure of choice for diagnosis, providing higher sensitivity and specificity, in addition to being non-invasive and capable of showing the isoechoic nature (in T1 and T2, differentiating it from tumors, synovial cysts, and arachnoid cysts), the size, and the anatomical relationships of the cyst. ${ }^{17}$ Moreover, this exam may provide prognostic information when it reveals possible atrophy or signs of change caused by the mass effect of the cyst. ${ }^{18}$

Myelography may reveal findings compatible with an expansive epidural process associated with a filling defect and there may be cases of false negatives depending on postural changes at the time of the exam, so performing this test in the prone position is recommended. ${ }^{19}$

In most cases, the radiological study has not proved useful in diagnosing these cysts, since it only shows us indirect indications resulting from the cystic mass effect, such as enlargement of the spinal canal, erosions and thinning of the pedicles or vertebral bodies, enlarged foramens, and an increase in the interpedicle distance. ${ }^{20}$

Among the differential diagnoses, a range of etiologies should be considered, such as congenital epidural arachnoid cysts (generally located behind the spinal cord, but without the fatty epidural layer as in cases of EAC), dermoid and epidermoid cysts (heterogeneous presentation in the $\mathrm{MRI}$ ), parasitic cysts (mainly in endemic regions, usually presenting as multiple small cysts at the time of diagnosis), and epidural hydatid cysts (associated with the destruction of the adjacent vertebra). ${ }^{2}$

For those patients who are symptomatic and refractory to drug treatment, the therapeutic gold standard is surgery, unlike the approach for asymptomatic patients, which is to wait. ${ }^{21}$ Thus, the objectives of surgery are to relieve the cyst-induced spinal cord and radicular compression in order to restore normal function and close the fistula, preventing recurrences. ${ }^{22}$

Surgical approaches that can be used include laminoplasty, hemilaminectomy or total laminectomy, ${ }^{21}$ and complete microsurgical excision of the cyst. ${ }^{23}$ The dural effect between the cyst and the subarachnoid space must be closed with clipping or suturing. ${ }^{3}$

In addition to these traditional techniques, minimally invasive alternatives have also been reported, such as selective laminectomy with image-guided fistula closure, derivations, and aspiration. ${ }^{22}$ In the case in question, taking the more lateral location of the cyst into account, they opted for a hemilaminectomy.

Recurrence of the symptomology or of the accumulation of cerebrospinal fluid is rare, ${ }^{24}$ and this finding has not been observed in our patient up until now.

\section{CONCLUSIONS}

In addition to being a rare and commonly asymptomatic pathology, adequate diagnostic investigation is essential to achieve a total cure for the symptomatic epidural arachnoid cyst, since this lesion can cause intense pain and other clinical manifestations that lead to a drastic reduction in the functional capacity of the patient.

All authors declare no potential conflict of interest related to this article.

CONTRIBUTION OF THE AUTHORS: Each author made significant individual contributions to this manuscript. FAAJ(0000-0002-3404-6555)* was the main author for the preparation of the manuscript. HAH(0000-0002-9236-6653) ${ }^{\star}$, DLB(0000-0002-2817-8105) ${ }^{\star}$, TRS(0000-0002-3730-8506)*, $\mathrm{JZJ}(0000-0001-9938-4857)^{\star}$, and PY(0000-0002-2817-8105)* organized the data presented in the case, conducted the literature review, and reviewed the article, in addition to contributing to the intellectual concept of the study. ${ }^{*} \mathrm{ORCID}$ (Open Researcher and Contributor ID).

\section{REFERENCES}

1. Cloward RB. Congenital spinal extradural cysts: case report with review of literature. Ann Surg. 1968;168(5):851-64

2. Gortvai P. Extradural cysts of the spinal canal. J Neurol Neurosurg Psychiatry.1963;26(3):223-30.

3. Oh JK, Lee DY, Kim TY, Yi S, HaY, Kim KN, et al. Thoracolumbar extradural arachnoid cysts: a study of 14 consecutive cases. Acta Neurochir (Wien). 2012;154(2):341-8.

4. Rohrer DC, Burchiel KJ, Gruber DP. Intraspinal extradural meningeal cyst demonstrating ball-valve mechanism of formation. J Neurosurg. 1993;78(1):122-5.

5. Kadono Y, Yuguchi T, Ohnishi Y-I, Iwatsuki K, Yoshimine T. A symptomatic spinal extradural arachnoid cyst with lumbar disc herniation. Case Rep Orthop.2015;1-5.

6. Liu JK, Cole CD, Kan P, Schmidt MH. Spinal extradural arachnoid cysts: clinical, radiological, and surgical features. Neurosurg Focus. 2007; 22(2):E6.

7. Kazan S, Ozdemir O, Akyüz M, Tuncer R. Spinal intradural arachnoid cysts located anterior to the cervical spinal cord. Report of two cases and review of the literature. J Neurosurg. 1999:91(2 Suppl):211-5.

8. Choi JY, Kim SH, Lee WS, Sung KH. Spinal extradural arachnoid cyst. Acta Neurochir (Wien). 2006;148:579-85

9. Lee TT, Arias JM, Andrus HL, Quencer RM, Falcone SF, Green BA.Progressive posttraumatic myelomalacic myelopathy: treatment with untethering and expansive duraplasty. J Neurosurg. 1997;86(4):624-8.

10. Apel K, Sgouros S. Extradural spinal arachnoid cysts associated with spina bifida occulta. ActaNeurochir (Wien). 2006;148(2):221-6.

11. James K, Liu MW, Chad D, Cole ND, Peter AJ, Meic H et al. Spinal extradural arachnoid cysts: clinical, radiological, and surgical features. Neurosurg Focus. 2007;22(2):E6.

12. Nabors MW, Pait TG, Byrd EB, Karim NO, Davis DO, Kobrine Al et al. Updated assessment and current classification of spinal meningeal cysts. J Neurosurg. 1988;68(3):366-77.
13. Rahimizadeh A, Abdolkhani E, Shariati M, Kahazchi M, Rahimizadeh S, Abbasnejad E. Spinal extradural arachnoid cysts. Coluna/Columna. 2013;12(2):112-8.

14. Suryaningtyas W, Arifin M. Multiple spinal extradural arachnoid cysts occurring in a child. J Neurosurg. 2007;106(2 Suppl):158-61.

15. Takagaki T, Nomura T, Toh E, Watanabe M, Mochida J. Multiple extradural arachnoid cysts at the spinal cord and cauda equina levels in the young. Spinal Cord. 2006:44(1):59-62.

16. Kim KS, Weinberg PE. Magnetic resonance imaging of a spinal extradural arachnoid cyst. Surg Neurol. 1986;26(3):249-52.

17. Spiegelmann R, Rappaport ZH, Sahar A. Spinal arachnoid cyst with unusual presentation. Case report J Neurosurg. 1984:60(3):613-6.

18. Prevedello DMP, Tatsui CE, Koerbel A, Grande CV, Cordeiro JG, Araújo JC. Ventral extradural spinal meningeal cyst causing cord compression: neurosurgical treatment. Arq Neuropsiquiatr. 2005;63(3B):855-8.

19. Ergun T, Lakadamyali $\mathrm{H}$. Multiple extradural spinal arachnoid cysts causing diffuse myelomalacia of the spinal cord. Neurologist. 2009;15(6):347-50

20. Rimmelin A, Clouet PL, Salatino S et al. Imaging of thoracic and lumbar spinal extradural arachnoid cysts: report of two cases. Neuroradiology. 1997;39(3):203-6.

21. Tokmak M, Ozek E, Iplikcioglu AC. Spinal Extradural Arachnoid Cysts : A Series of 10 Cases. J Neurol Surg A Cent Eur Neurosurg. 2015;76(5):348-52.

22. QiW, Zhao L, Fang J, Chang X, XuY. Clinical characteristics and treatment strategies for idiopathic spinal extradural arachnoid cysts: a single-center experience. Acta Neurochir (Wien). 2015;157(3):539-45.

23. Payer M, Brühlhart K. Spinal extradural arachnoid cyst: review of surgical techniques. J Clin Neurosci. 2011;18(4):559-60.

24. Kumar A, Sakia R, Singh K, Sharma V. Spinal arachnoid cyst. J Clin Neurosci. 2011;18(9):1189-92. 